\title{
РОЗВИТОК ОПЕРАЦІЙНОГО КОМПОНЕНТА ПІЗНАВАЛЬНОЇ АКТИВНОСТІ СТУДЕНТІВ ВИЩИХ ПЕДАГОГІЧНИХ НАВЧАЛЬНИХ
} ЗАКЛАДІВ

\footnotetext{
У статті розкрито структуру операційного компонента пізнавальної активності майбутніх учителів у вищому навчальному закладі та розглянуто шляхи та методи розв'язання проблеми розвитку операційного компонента пізнавальної активності.

Ключові слова: операційний компонент, пізнавальна активність, розумові операџії, властивості мислення, мовнорозумова діяльність, діалогічне навчання.
}

В статье раскрыта структура операционного компонента познавательной активности будущих учителей в высшем учебном заведении и рассматриваются пути и методы решения проблемы развития операционного компонента познавательной активности.

Ключевые слова: операчионный компонент, познавательная активность, умственные операчии, свойства мышления, языковая интеллектуальная деятельность, диалогическое обучение.

The article revealed the structure of the operational component of the cognitive activity of future teachers in higher education and the ways and methods of solution of the operational component of cognitive activity.

Key words: operational component, cognitive activity, mental operations, properties of thought, language and mental activity, dialogical learning.

Основним завданням нині є модернізація освіти. Здатність сприймати зміни і творити їх - це найважливіша характеристика способу життя людини у XXI столітті. Освіта має набути інноваційного характеру, тобто постійно змінюватися, доповнюватися, удосконалюючи вміння i навички, оскільки знання, які здобуває студент, мають велике значення, i це не єдиний критерій. Поряд із цим постає потреба розвитку здатності студента до самостійного засвоєння знань: навчати вчитися, формувати уміння так чи інакше здобуті знання застосовувати у практичній діяльності. Активним у навчанні може бути тільки той студент, який усвідомлено оперує предметом діяльності; якщо він має визначенні знання про цей предмет i володіє способами діяльності, тобто інтелектуальними уміннями.

Проблема обгрунтування сутності пізнавальної активності учнів у процесі навчання знайшли відображення в дослідженнях дидактів, психологів, методистів: Л. Аристової, Д. Вількєєва, Е. Голанта, М. Данилова, Т. Кудрявцева, І. Лернера, М. Махмутова, В. Онищука, Н. Половнікової, В. Пилипчука, О. Савченко, М. Скаткіна, Л. Скуратівського, Т. Шамової та інших.

У наукових дослідженнях розкрито понад 50 показників активності: ініціативність (В. Бєлєнький, Л. Анциферова, П. Кряжев, Е. Шорохова); інтерес (Г. Щукіна, Л. Зюбін, А. Спірін), позитивне ставлення до діяльності (А. Умарова, Е. Ануфрієв); вольові якості особистості, що виявляються у завзятості, наполегливості, умінні доводити почату справу до кінця, опору впливам, що відволікають (Е. Ануфрієв, Л. Анциферова), енергійність, інтенсивність діяльності (В. Бєлєнький, Е. Ануфрієв). Автори виокремлюють і такі показники, як цілеспрямованість і спрямованість, самостійність, усвідомленість діяльності, творчість та ін.

Mета статmi - розкрити ключові аспекти проблеми формування операційного компонента пізнавальної активності майбутніх учителів, зокрема учителів хімії та біології. На нашу думку, розв'язання цієї проблеми вимагає ефективного впровадження діалогічного навчання, що дозволить розвивати у майбутніх педагогів такі якості знань, як оперативність, що передбачає готовність та вміння студента до застосовування знань у подібних та варіативних ситуаціях, а також гнучкість знань: активне залучення вже відомих знань при зміні навчальних ситуацій, тобто підвищення загальної якості знань студентів.

Підвищення наукового рівня сучасної вищої освіти, з одного боку, створює умови для формування мотивів активної діяльності студентів, а 3 іншого, - вимагає використання визначеної системи прийомів, методів і організаційних форм, що забезпечують активне навчання.

Вивчення психолого-педагогічної літератури з проблеми формування професійних умінь студентів свідчить, що цьому питанню приділяється постійна увага в теорії педагогіки та практики вищої освіти. Важливість дослідження проблеми підтверджується нині й тим, що метою підготовки в умовах переходу до ринкових відносин $є$ підготовка висококваліфікованих, конкурентоспроможних кадрів $з$ високим рівнем професійних умінь, знань, навичок, що відповідають вимогам науковотехнічного прогресу, формування в них наукового світосприйняття, творчого мислення.

У практиці вищої школи викладачі формуванню системи знань студентів приділяють значну увагу, оволодінню ж способами діяльності - меншою мірою. Без цього не можливо здійснити активізацію навчання.

Соціальним досвідом, накопиченим людством у своєму історичному розвитку студент може 
опанувати, якщо він буде озброєний способами навчання. Часто відставання студента в навчанні виникає тому, що він цими способами не володіє. Завдання полягає в тому, щоб у процесі навчання поступово формувати в студентів уміння самостійно добувати знання, оцінювати їх і застосовувати на практиці. Правильно організоване навчання, що передбачає залучення всіх студентів до активної пізнавальної діяльності і використання спеціальних завдань на розвиток мислення, позитивно позначається на їхньому розумовому розвитку.

Як одну 3 найголовніших ознак пізнавальної активності передбачає операційний компонент. Способи виконання дії О. Леонтьєв називає операціями. Вони утворюють «технічний» склад дії й завжди залежать від умов, у яких досягається поставлена мета. У силу цього дія відповідає не лише своїй безпосередній дії, але також і тим умовам, у яких ця мета задана і які визначають сам спосіб виконання дії. Уточнюючи цю думку, О. Леонтьєв уважає, що операція визначається метою, даною за конкретних умов, що потребують певного способу дії.

Будь-яка операція як спосіб виконання дії, що визначається завданням, може сформуватися, згідно з О. Леонтьєвим, двома істотно різними шляхами. Перший шлях - зливання в процесі діяльності окремих видів дій у єдину складну дію. Тут приватні дії, що були раніше самостійними, тобто спрямованими на мету, входячи до складу нової складної дії (як його складники), займають у ньому структурне місце умов його виконання, тобто перетворюються на операції. Це так звані свідомі операції. Вони відрізняються своєю гнучкістю й керованістю. Другий шлях формування операцій здійснюється через пристосування дії до нових умов його виконання або до чужих дій у ситуації відтворення певної операції - зразка.

Головне значення в освіті має, звичайно, перший шлях формування операцій, коли «свідомі операції формуються спочатку як цілеспрямовані процеси, які лише згодом можуть у деяких випадках приймати форму автоматизованої навички. Для цього необхідно поставити студента перед такою новою метою, коли використана ним дія стане засобом виконання іншої дії. При цьому дії, спрямовані раніше на досягнення часткових цілей, що складають підцілі нової мети, повинні стати засобами досягнення нової складної мети в процесі нової складної дії» [1, с. 175].

Однак у навчанні занадто важливим є і другий, указаний О. Леонтьєвим, шлях стихійного формування операцій. На нижчих, початкових ступенях навчання - в основному через наслідування деяких еталонів, на вищих -через систематичні випробування та помилки, через гомеостатичне пристосування до нових умов, що не виключає раптового знаходження шуканого способу дії (операції) «за здогадкою».

Не зупиняючись детально на ретельно представленій у роботах О. Леонтьєва проблемі відображення та ії̈ співвідношення з діяльністю, підкреслимо в аспекті нашого аналізу лише той факт, що людська діяльність у своєму розвитку від пристосувальної до продуктивної підкоряється меті уявленню про той об'єктивний результат, на досягнення якого вона спрямована. Отже, уявність відображеного в мозковій моделі предмета (мети) дії і є обов'язкова умова людської діяльності, що складає основу зсуву в людини мотиву діяльності на мету (предмет) дії. При цьому дія, включена в діяльність, перетворюється в нову діяльність.

Однак, перш ніж більш докладно уявити концепцію зсуву, необхідно усвідомити, яким чином відбувається розподілення предмета діяльності та ії мотиву, або, інакше кажучи, який механізм народження дії.

Розподілення предмета й мотиву діяльності є результат виокремлення з єдиної діяльності певних операцій. Для індивіда вони перетворюються в самостійні дії. Що ж до відношення до колективного процесу праці залишаються окремими операціями. Дії людини, спрямовані на предмет безпосереднього задоволення іiі потреби, стають можливими лише тоді, коли сенс іiі дій усвідомлюється нею. Так народжується дія, а разом 3 народженням цієї головної «одиниці» діяльності людини виникає і основна, суспільна за своєю природою «одиниця» людської психіки сенс для людини того, на що спрямована діяльність.

Співвідношення між діяльністю й дією полягає в тому, що мотив діяльності може зсуватися й переходити на предмет дії. І тоді дія перетворюється в діяльність. Сам процес такого перетворення $\epsilon$ конкретно-психологічою основою виникнення провідної діяльності, а отже, переходу від однієї стадії iii розвитку до іншої. Обов’язкова умова цього переходу - перетворення тільки «знайомих», «зрозумілих» мотивів за визначених умов на системоутворювальні й дієздатні. Становлення сенсоутворювальних мотивацій змінює й уявлення людини як про саму мету, так і про дії, спрямовані на $\dddot{11}$ досягнення.

До операційного компонента входять надпідрозділи: 1) розумові операції та розумові вміння, 2) властивості мислення, 3) мовно-розумова діяльність. Операційний компонент забезпечує процесуальний перебіг пізнавальної активності. Перший підрозділ операційного компонента пізнавальної активності включає такі операції мислення: аналіз, порівняння, узагальнення, систематизація, активне перенесення, визначення причинно-наслідкових зв'язків та логічних міжпредметних i внутрішньо-предметних зв'язків, доказ-спростування. До другого підрозділу належать ті характерні риси мислення, які «закріплюють» у собі вияви пізнавальної активності: самостійність мислення як уміння людини доходити певного висновку, встановлювати важливі 
закономірності і застосовувати на практиці набуті знання, тобто самостійно міркувати; критичність мислення; конструктивність мислення як уміння знаходити раціональні й оптимальні шляхи розв’язання завдання чи проблеми; перетворюваність мислення як «переструктурування», перетворення здобутих знань задля їх поглибленого осмислення та подальшого конструктивного використання; проблемність мислення як сприйнятливість до суперечностей дійсності, вміння осягнути проблему; сміливість мислення як відсутність страху помилки, прагнення подати свої думки на розгляд інших, навіть за несприятливих обставин; глибина мислення як здатність усвідомити сутність явищ; широта мислення як намагання різнобічного та різноаспектного вивчення явищ чи об'єктів; гнучкість мислення як установлення різноманітних логічних зв'язків. Становлення та розвиток властивостей мислення визначаються сформованістю операцій мислення та розумових умінь. До підрозділу «мовно-розумова активність» операційного компонента включаємо вияви пізнавальної активності в мовній діяльності: вміння передавати зміст матеріалу своїми словами, прагнення урізноманітнювати висловлення своєї думки, логічність і точність мовних умінь, як уміння формулювати головне, чіткість мовних висловлювань як уміння через слово передавати думку (мовна імпровізація).

Під активними розумовими діями й операціями мається на увазі такий рівень їхньої сформованості, що дає студентам можливість самостійно шукати і визначати спосіб виконання навчального завдання.

Це складові, записані в порядку зменшення їх факторної ваги: критичність мислення, різноманітність формулювання проблем, передбачення; доведення-спростування, логічність, уміння передати думку своїми словами, встановлення міждисциплінарних зв’язків, точність висловлення, виділення головного, конструктивність мислення, активне перенесення, систематизація, узагальнення, встановлення причинно-наслідкових зв'язків, визначення понять, широта мислення, самостійність мислення, сміливість мислення, глибина мислення, гнучкість мислення, проблемність мислення, аналіз мислення.

Наявні такі види мислення: діалектичне - уміння бачити в явищі суперечності, тенденції розвитку, зародження нових; логічне - встановлення узагальнених зв'язків між новими знаннями $і$ раніше засвоєним матеріалом, приведення їх у певну систему; абстрактне - абстрагування від неістотних, другорядних ознак, виокремлення загальних та істотних i на цій основі формування абстрактних понять; узагальнювальне - знаходження загальних принципів і способів дій, що поширюються на певну низку явищ; категоріальне - уміння об'єднувати поняття в класи і групи на підставі певних істотних ознак подібності; теоретичне - здатність до засвоєння знань високого рівня узагальнення, розуміння наукових засад і принципів розвитку тих чи тих галузей знань, виявлення залежності та закономірності наявних між явищами зв'язків; індуктивне - рух думки від окремого до загального, від фактів до узагальнень, висновків; дедуктивне - рух думки від загального до окремого; алгоритмічне - неухильне дотримання інструкції, яка вказує чітку послідовність дій, що забезпечує отримання результату; технічне - розуміння наукових засад i загальних принципів виробничих процесів; репродуктивне - актуалізація засвоєних знань для розв'язання завдань відомого типу або виконання дій у знайомих умовах; продуктивне - самостійне розв'язання людиною нових завдань на основі набутих знань, а також із використанням нових даних, способів і засобів, необхідних для їх розв'язання; системне - здатність виявляти зв'язки між науками, розуміти загальнонаукові закони, покладені в основу їх розвитку, мати загальні уявлення про закономірності розвитку природи $\mathrm{i}$ суспільства.

Сутність засвоєння знань і умінь грунтується на теорії поетапного формування розумових дій, а саме процес системного оволодіння розумових дій, що відбувається в результаті інтеріоризації, тобто переходу всередину відповідної розумової дії. Психічна діяльність є результатом перенесення зовнішніх матеріальних дій у план відображення- у план сприймання, уявлення і понять. Процес такого перенесення здійснюється за етапами, на кожному з яких відбувається нове відображення i відтворення дії та іiі систематичне перетворення. П. Гальперін визначає шість етапів формування будь-якого нового поняття й уміння.

Процес формування професійних умінь студентів відбувається в логічній послідовності за такими етапами: 1 етап - створення мотивації; 2 етап - з'ясування орієнтовної основи дій у системі (моделі об’єкта, навчального алгоритму «операції» за розпізнаванням або відтворенням об’єкта); 3 етап формування дії у матеріалізованому вигляді (дія з матеріалізованими і матеріальними об'єктами; дія 3 матеріалізованими позначеннями); 4 етап - формування дії в «гучній мові», що передбачає повне і правильне виконання дії своїми словами та виконання дії як «своїми словами», так і за встановленою формулою; 5 етап - формування дії в зовнішній мові про себе; 6 етап - формування дії у внутрішній мові.

Система засобів активізації навчання студентів спрямована на мобілізацію усіх внутрішніх сил інтелекту, волі і почуттів, що значно підвищує рівень свідомості засвоєння знань. При цьому в навчальній діяльності викладача зростає роль комплексного використання засобів впливу на студента.

Тому можна стверджувати, що розвиток активності мислення - це насамперед організація 
діяльності студентів, спрямована на усвідомлення і рішення навчальних проблем.

Про сформованість таких розумових операцій, як порівняння, зіставлення, аналіз, синтез, узагальнення, викладач може судити по вмінню виокремлювати істотне, головне. Саме вміння виокремлювати істотне широко пов'язане з іншими процесами і властивостями мислення. Наприклад, для того, щоб коротко сформулювати основну думку розповіді прочитаного тексту чи викладача, студент повинний виконати велику аналітико-синтетичну роботу: зіставити, пов'язати факти, зробити висновки. Аналіз досвіду і досліджень показує, що для формування зазначених умінь варто зосереджувати увагу студентів у процесі навчання на головних питаннях теми, навчати їх співвідносити факти, явища з центральною проблемою, окремі закони - 3 теорією, вчити їх у процесі спостереження вловлювати істотні ознаки явищ, процесів, а 3 цих ознак виокремлювати загальне.

Перегляд традиційних уявлень про структуру розумового акту, що відповідають теоретичній моделі індивідуального мислення людини, і включення як модель дослідження різних типів діалогічної взаємодії відкриває нові можливості вивчення ролі діалогу в розвитку мислення. Модель повної структури мислення учасника діалогічного рішення може бути представлена такими ланками: а) породження проблеми і формулювання розумового завдання, б) пошук, реалізація розв'язання завдання , в) обгрунтування знайденого. Процес розв'язання навчального пізнавального завдання 3'являється у вигляді двох ланок, що перемежовуються між собою: «мислення для себе» і «мислення для іншого» $[2$, с. 35$]$.

Проведені в останні роки дослідження рефлексивної організації мислення, розроблення внутрішнього діалогу показують правомірність тлумачення мислення не тільки як особливої форми взаємодії суб'єкта з об'єктом, але і як особливого діалогу, при цьому основною характеристикою діалогу $є$ не наявність двох чи кількох суб'єктів, а наявність двох чи кількох взаємодіючих значеннєвих позицій, що виражаються в мові тими, що говорять (зовнішній діалог) чи одним, що говорить (внутрішній діалог). За наявності внутрішньої проблемної ситуації, крім того, максимально актуалізується потреба студента у змістовному спілкуванні. Причому таке спілкування відрізняється високою діалогічністю. До умінь навчатися належать і спеціальні вміння та навички, що формуються у вивченні тої чи іншої навчальної дисципліни. За роки навчання у ВНЗ студент здобуває безліч різноманітних умінь. Поміж них є такі, що є опорою у вивченні різних наук. Так, наприклад, уміння користуватися рівнянням для розв'язання завдань необхідно не тільки для придбання і застосування математичних знань, але й у хімії та біології. Отже, є низка спеціальних умінь, що можуть бути інструментом у різних галузях знань, і тому їх доцільно залучати до складу способів навчання.

Психологічна наука стверджує, що продуктивне мислення завжди пов'язане 3 розв'язанням проблеми. «Мислення звичайно починається чи 3 питання проблеми, чи 3 подиву, здивування, із суперечності. Цією проблемною ситуацією визначається залучення особистості в розумовий процес; він завжди спрямований на розв'язання якогось завдання» [4, с. 127].

Варто зауважити, що мислення не тільки починається із завдання, проблеми, але і надалі протікає у формі розв'язання послідовних пізнавальних завдань, проблеми загалом. Отже, можна стверджувати, що активізація навчання $є$ насамперед організацією дій учнів, спрямованих на усвідомлення і розв'язання навчальних проблем.

Отже, у внутрішній проблемній ситуації активізуються не тільки розумові, а й інші пізнавальні процеси сприймання - увага, уява, пам'ять. Це створює передумови для підтримання зацікавленості в невідомих знаннях, інтересу до пошуку тощо.Відповідно, операційний компонент визначає систему шляхів, засобів і прийомів формування пізнавальної активності студентів. Вияв пізнавальної активності уможливлений на основі сформованості найскладніших мистецьких якостей та розумових умінь особистості.

1. Леонтьев А. Н. Деятельность. Сознание. Личность / Александр Николаевич Леонтьев. - М. : Прогресс, 1983. - 365 с. 2. Матюшкин А. М. Загадки одаренности / Алексей Михайлович Матюшкин. - М. : Школапресс, 1993. - 128 с. 3. Мар'яненко Л. В. Особливості структурної організації пізнавальної активності учнів / Л. В. Мар’яненко // Педагогіка і психологія. - 1997. - № 1. - С. 14-22. 4. Рубинштейн С. Л. Проблемы общей психологии / Сергей Леонидович Рубинштейн. - М. : Педагогика, 1973. - 423 с. 